\title{
Impact of Firm Specific Factors on Financial Performance: A Comparative Study of Life and Non-Life Insurance Companies in Nepal
}

\author{
${ }^{1}$ Bhupal Jaishi \\ ${ }^{2}$ Resam Lal Poudel \\ ${ }^{1,2}$ Faculty of Management, Prithvi Narayan Campus, Pokhara, Nepal
}

Article History: Submitted 13 February 2021; Reviewed 24 April 2021; Accepted 29 April 2021 Corresponding Author: Resam Lal Poudel, Email: resampoudel@pncampus.edu.np DOI: https://doi.org/10.3126/paj.v4i0.37014

Copyright 2021 (c) Author/s and Centre for Research and Innovation. This work is licensed under a Creative Commons Attribution 4.0 International (CC BY 4.0) License.
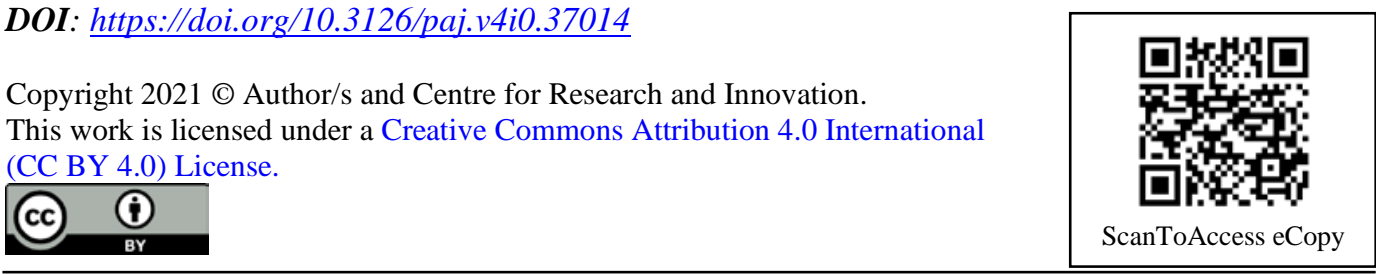

\begin{abstract}
The empirical research has been carried out to examine the firm specific factors composition and its impact on financial performance of life and non-life insurance companies in Nepal. This paper employs the descriptive as well as causal-comparative research design. The study comprises of a panel data set of 14 insurance companies listed in Nepal Stock Exchange (NEPSE) with 140 observations covering a period of 10 years from 2009/10 to 2018/19. The result exhibits that the insurance companies having a high debt ratio have better financial performance. It also reveals that a higher proportion of debt ratio and tangible assets increases return in assets. On the other side, a lesser proportion of equity, firm size and liquidity decreases the return on assets of the insurance companies in Nepal. The study raises understanding of impacts of firm specific factors on financial performance and provides an empirical evidence that the total debt ratio, equity to the total assets ratio, leverage, firm size, liquidity and tangibility are the significant factors in determining the financial performance of Nepal's insurance companies. The non-life insurance companies tend to perform better in term of financial performance measured by earning per share and return on assets. The study leads to practical implications for insurance companies and regulatory bodies. The insurance companies of Nepal interested to improve their financial performance should focus on increasing their leverage and long-term investment and decreasing the proportion of equity, firm size and liquidity.
\end{abstract}

KEYWORDS: Firm specific factors, financial performance, liquidity, tangibility

\section{INTRODUCTION}

The insurance companies are non-banking financial intermediaries that channelize funds from the savers to the users. The insurance sector is the major 
component of the financial system as it supports different sectors of the economy. This sector provides unique services for the growth and development of every aspect of the economy. The importance given to this sector has been increasing every day in both developed and developing countries. The basic reason for this is the contribution provided on the economic growth process and the level of national wealth (Kaya, 2015). Prior empirical studies have highlighted a positive association between insurance development and economic growth (Enz, 2000).

The capital structure is the financial combination or mix of sources of funds used to establish and expand the business. It is one of the ways to generate funds for investment. The proportion of equity and debt capital is maintained under the guidance of financial policy as a financing decision. It is the capital structure that has a linkage with the corporate ability to fulfill the stakeholder's objectives (Simerly \& Li, 2000). The capital structure decision is the vital one for business investment and the financial performance of an enterprise that is directly affected by the investment decision. The firm specific variables mainly denote the internal factors that directly influence the profitability of the business. Prior studies have found the relationship between firm specific variables namely liquidity, tangibility, net premium, growth rate, size on profitability and performance of insurance companies. For instance, the firm specific factors included by the study conducted by Bawa and Chattha (2013) were liquidity, size and solvency. They found that there is a positive relationship of liquidity and size on the profitability of life insurance companies in India. Ajao and Ogieriakhi (2018) also examine the impact of firm specific variables on financial performance. They concluded that the size and growth rate were the important factors affecting the performance of insurance companies in Nigeria.

The financial performance of an insurance company is measured in terms of net premiums earned, return on investment, return on equity and profits earned from underwriting activities (Chen \& Wond, 2004). It can be divided into the profit performance and investment performance measures. The organization's earning and increase in the value as indicated by the increment of share price are the major indicators of financial performance. The major factor influencing the performance of insurance companies is internal factors, namely the company's size, company's age, underwriting risk and leverage (Curak et al., 2011 \& 2011; Ismail, 2013; Majumdar, 1997; Malik, 2011; Shiu, 2004). Prior studies exploring the relationship between the capital structure and financial performance in the Nepali financial institutions revealed both positive and negative relationships. Those studies are focused on commercial banks, trading and manufacturing companies rather than the insurance sector. The insurance sector as a nondepository institution has been facing challenges to incorporate the optimal capital structure to increase their financial performance.

In the light of the above theoretical underpinnings, the present study provides an empirical evidence on the impact of firm specific factors and the capital structure on financial performance of insurance companies in Nepal and compares the results between life and non-life insurance companies of Nepal. This study also adds to the literature on the capital structure and financial performance, especially the insurance companies.

\section{LITERATURE REVIEW}

The study conducted by Sunder and Myers (1999) reveals that there is a positive association between tangibility and debt ratio. On the contrary, there is a negative association between debt ratio with the company's profitability. Safarova (2010) explored that firm's size is the most important factor determining firm performance, 
followed by the growth and leverage. Tangibility, corporate governance, cash in hand and risk have less association with a firm's operating results. Salim and Yadav's (2012) empirical results depicts that long term debt ratio (LTD) and short term debt ratio (STD) and (TD) harm profitability measured by return on assets (ROA), return on equity (ROE) and earning per share (EPS). Besides, the organizational growth directly influenced the financial performance for all the sectors. Mohammad et al. (2013) conclude that a company's performance which is measured by EPS and ROA has a negative impact on the capital structure. Goyal (2013) showed that there is a positive relationship between short-term debt with profitability measured by ROA, ROE and EPS. Naeem et al. (2016) concluded that there is a positive relationship between profitability, tangibility, interest rate, growth rate and capital structure.

Maharjan (2017) examined the effect of capital structure on profitability of Nepali-commercial banks and indicated that long term debt to equity ratio, total debt to equity ratio, bank size and liquidity position is negatively related to firm performance. However, there is a positive relationship between credit risk with firm performance. Almajali and Shamsuddin (2019) have revealed results that short term and long term debt were positive with the ROE though negatively with Tobin`s Q. The result also concludes that financial leverage was positively significant with profitability. Jaishi (2020) concluded that the insurance companies having a high debt ratio have better financial performance. An increase in debt ratio and tangibility increases return on assets and an increase in equity, size and liquidity decreases return on assets in the industry. Multiple regression models were used to test the effect on financial performance variables. Bhattarai (2020) also reveals that financial performance has been influenced by equity to total assets, leverage and tangibility in Nepal's insurance companies`cases.

The existence of business organization and maximization of shareholders' wealth is critical to the capital structure decision of a company (Akintoye 2008). Many studies have been undertaken to investigate the relationship between the capital structure and financial performance. Some studies revealed a positive association between the capital structure and performance (Akintoye 2008; Dare and Sola 2010) while others reported a negative association between the capital structure and financial performance (Iorpev and \& Kwanum 2012). In the contrary to positive and negative relationships, some studies indicated that there is no association between the capital structure and performance (Prahlathan \& Rajan, 2011).

Most of the past studies in the Nepali context either explored the financial performance and capital structure aspects. Some of the studies analyzed the impact of capital structure and financial performance in the banking sector. In the Nepali context, the studies examining the impact of capital structure on the financial performance of non-depository institutions and the comparative study between life and non-life companies with the variables included below is still to be explored. There are a few studies that incorporates the relevance of capital structure theories in the context of Nepal and factors that influence the capital structure decision using more recent data. Hence, there is a need to examine the impact of capital structure on firm performance and compare the capital structure and financial performance variables between life and non-life insurance companies in the context of Nepal.

\section{DATA AND METHODS}

The study follows the descriptive and causal comparative research design using positivism philosophy and deductive approach. The descriptive research design has been adopted for fact-finding and adequate information gathering. It explains the real and actual conditions, situations and facts. The causal-comparative research design has been 
used to establish the cause and effect relationship between firm specific factors and financial performance variables. The quantitative data have been collected from the secondary sources obtained from the annual reports of selected insurance companies. Balance sheets and income statements extracted from annual reports for the selected insurance companies have been the fundamental data source of this particular study. The panel data are used to fulfill the objective of the study.

The population of the study comprises of all the insurance companies i.e. 23 listed in Nepal Stock Exchange (NEPSE) as of 17 July 2019. These companies have been divided into life and non-life insurance companies using a stratified sampling method. Out of total life insurance companies, seven life insurance companies have been selected purposively which includes 10 years of data. Seven non-life insurance companies have been selected using a simple random sampling to compare the result of life and non-life insurance companies with an equal number of observations. The total number of observations of the study includes 140 (10 years from the fiscal year 2009/10 to 2018/19 of 14 companies). The observation sample has been presented in Appendix I.

The study employs both descriptive and inferential analysis. The descriptive statistics include mean and standard deviation of the independent variables and dependent variables that depicts the characteristics of sample insurance companies. Inferential statistics namely correlation and regression analysis has been used in the study to explore the relationship and impact of independent variables on dependent variables. An independent sample t-test has been employed in the study to find the differences in mean value of life and non-life insurance companies. It explains the different statistical tests of significance for validation of models like t-test and F-test. Normality was checked with the help of a normal P-P plot and found no outliers and data were normal. Multicollinearity was checked by calculating the Variance Inflation Factor (VIF) that was less than 4.

\section{Model Specification}

The econometric models employed in this study tries to analyze the relationship between firm specific factors and financial performance. The following regression model has been used in the study to examine the empirical effect of firm specific factors on the financial performance of Nepali insurance companies. The following models have been used to examine the empirical effect based upon the previous studies of Berger (1995), Rajan and Zingales (1995), Sunder and Myers (1999), Zeitun and Tian (2007), Goyal (2013) and Singh and Bagga (2019). The function of dependent variables (i.e. financial performance) takes the following form:

Financial performance $=f($ TDR, ETA, SIZE, LQ, TAN $)$

More specifically, the given model has been segmented into the following models:

\section{Model 1}

In the first model, TDR, ETA, SIZE, LQ, TAN and EPS are taken as independent variables and ROA as dependent variables. The model has been used to see the impact of those independent variables on the financial performance of insurance companies measure by ROA. The model has been presented as follows:

$$
\mathrm{ROA}=\beta_{0}+\beta_{1} \mathrm{TDR}+\beta_{2} \mathrm{ETA}+\beta_{3} \mathrm{SIZE}+\beta_{4} \mathrm{LQ}+\beta_{5} \mathrm{TAN}+\beta_{6} \mathrm{EPS}+\mathrm{e}
$$

\section{Model 2}

In the second model, TDR, ETA, SIZE, LQ, TAN and ROA are taken as independent variables and EPS as dependent variables. The model has been used to see 
the impact of those independent variables on the financial performance of insurance companies measure by EPS. The model has been presented as follows:

$\mathrm{EPS}=\beta_{0}+\beta_{1} \mathrm{TDR}+\beta_{2} \mathrm{ETA}+\beta_{3} \mathrm{SIZE}+\beta_{4} \mathrm{LQ}+\beta_{5} \mathrm{TAN}+\beta_{6} \mathrm{ROA}+\mathrm{e}$

Where,

$\beta_{0}$ is the constant term and $\beta$ is the coefficient of the variable

ROA $=$ Return on assets

EPS=Earnings per share

TDR=Total debt ratio

$\mathrm{ETA}=$ Equity to total assets

LEV=Leverage

SIZE $=$ Firm size

LQ=Liquidity

TAN=Assets tangibility

$\mathrm{e}=$ Error term

\section{Variables and their measurement}

Return on assets measures how efficiently a company can manage its assets to produce profits during a period. It has been calculated as a percentage of net profit after tax divided by the total assets. Earnings per share measure a firm's profitability by revealing how much profit a company generates with the money that shareholders have invested. It has been calculated as rupees of net profit available to shareholders divided by the number of shares outstanding. The debt ratio shows the ratio of debt to total assets. It is calculated as the percentage of the total debt of a business divided by its total assets. Equity to total assets reveals capital adequacy and captures the general safety and soundness of the financial institution. It is calculated as the percentage of total equity to total assets.

The firm's size is a factor that determines the company's base for better financial performance and total corporate investment. The amount of total assets of a firm indicates the firm's size. Liquidity refers to the company's capability to pay the short term financial obligation. It indicates the short-term solvency of the business. The liquidity of a firm is generally expressed as the ratio of current assets and current liabilities. The tangibility of assets is an important variable to describe investment on the long term (fixed) assets out of the total assets. It is calculated as the percentage of fixed assets to the total assets.

\section{RESULTS AND DISCUSSION}

\section{Description of Firm Specific Factors and Financial Performance Variables}

Debt capital and equity are the major sources of funds for a firm's investment. An effective mobilization of fixed and current assets generates revenue for the business. Return on assets and earnings per share are used as the financial performance measurement tool. The position of these study variables has been described through descriptive statistics.

\section{Table 1}

Descriptive Statistics of Major Variables

\begin{tabular}{lllll}
\hline Variables & Minimum & Maximum & Mean & Standard deviation \\
\hline ROA & -20.83 & 18.62 & 4.10 & 4.26 \\
EPS & -85.67 & 166.85 & 27.14 & 28.22 \\
TDR & 1.05 & 90.45 & 33.54 & 27.69 \\
\hline
\end{tabular}

Prithvi Academic Journal, Volume 4, May 2021 [pp. 39-55] 


\begin{tabular}{lllll}
\hline ETA & 9.55 & 98.95 & 66.46 & 27.69 \\
SIZE & 282.33 & 78383.62 & 7409.54 & 12684.20 \\
LIQ & .26 & 26.10 & 4.47 & 4.83 \\
TAN & .28 & 34.75 & 4.65 & 5.48 \\
\hline
\end{tabular}

The two major dependent variables, i.e. ROA and EPS depict positive and negative results. The ROA ranges from -20.83 percent to a maximum of 18.62 percent and an average of 4.10 percent. It indicates that ROA of Nepali insurance companies is less than five percent, which is not overwhelming. The next dependent variables, i.e. EPS ranges from Rs -85.67 to Rs 166.85 , which indicates results for the insurance companies in Nepal. The average EPS is Rs. 27.14 of the sample companies indicating better performance in terms of EPS. The capital structure variables such as the total debt ratio vary from a minimum of 1.05 percent to a maximum of 90.45 percent leading to an average of 33.54 percent and equity to total assets ratio fluctuates from a minimum of 9.55 percent to a maximum of 98.95 percent leading to an average of 66.46 percent.

The firm `s investment on total assets indicated by the firm size ranges from Rs.282.33 million to Rs.78383.62 million leading to an average of Rs. 7409.54 million. Liquidity ratio varies from $0.26: 1$ to $26.10: 1$ and average of $4.47: 1$. Assets tangibility varies from a minimum of 0.28 percent to a maximum of 34.75 percent leading to an average of 4.65 percent. There is a constant increase in equity financing and total assets investment. All these variables indicate variations in the study variables.

\section{Variable-Wise Comparative Analysis of Life and Non-Life Insurance Companies}

The comparative position of capital structure and financial performance variables between life and non-life insurance companies of Nepal has been presented in Table 2. The table shows the position of ROA, EPS, TDR, ETA, firm's SIZE, LIQ and TAN of Nepali life and non-life insurance companies throughout the study period.

Table 2

Comparison between Life and Non-Life Insurance Companies

\begin{tabular}{|c|c|c|c|c|c|c|c|c|c|c|c|c|c|c|}
\hline \multirow[b]{2}{*}{ Year } & \multicolumn{2}{|c|}{ ROA(\%) } & \multicolumn{2}{|c|}{ EPS (Rs) } & \multicolumn{2}{|l|}{ TDR(\%) } & \multicolumn{2}{|l|}{$\begin{array}{l}\text { ETA } \\
\end{array}$} & \multicolumn{2}{|c|}{$\begin{array}{l}\text { SIZE(Rs in million) } \\
\end{array}$} & \multicolumn{2}{|c|}{ LQ(Times) } & \multicolumn{2}{|c|}{ TAN(\%) } \\
\hline & Life & $\begin{array}{l}\text { non- } \\
\text { life }\end{array}$ & life & $\begin{array}{l}\text { Non- } \\
\text { life }\end{array}$ & Life & $\begin{array}{l}\text { non- } \\
\text { life }\end{array}$ & Life & $\begin{array}{l}\text { Non- } \\
\text { life }\end{array}$ & Life & non-life & life & $\begin{array}{l}\text { non- } \\
\text { life }\end{array}$ & life & non-life \\
\hline 2009/10 & 2.70 & 4.81 & 18.54 & 23.96 & 11.25 & 53.47 & 88.75 & 46.53 & 2402.44 & 503.01 & 7.20 & 1.56 & 2.68 & 11.99 \\
\hline 2010/11 & 2.38 & 5.18 & 8.41 & 30.73 & 12.62 & 54.28 & 87.38 & 45.72 & 4057.64 & 589.20 & 6.30 & 1.26 & 3.65 & 12.18 \\
\hline 2011/12 & 3.86 & 4.25 & 48.62 & 29.30 & 11.8 & 56.78 & 88.20 & 43.22 & 5318.66 & 723.44 & 5.06 & 1.18 & 3.5 & 10.08 \\
\hline $2012 / 13$ & 3.76 & 6.44 & 50.00 & 43.38 & 9.04 & 53.37 & 90.96 & 46.63 & 6749.20 & 882.7 & 7.74 & 1.45 & 3.10 & 8.82 \\
\hline 2013/14 & 2.37 & 8.32 & 22.20 & 42.23 & 9.33 & 56.87 & 90.67 & 43.13 & 7405.78 & 1064.65 & 9.67 & 3.77 & 2.44 & 7.77 \\
\hline $2014 / 15$ & 1.03 & 7.59 & 12.86 & 38.3 & 7.22 & 60.61 & 92.78 & 39.39 & 11328.44 & 1532.33 & 11.09 & 1.38 & 2.01 & 5.44 \\
\hline 2015/16 & 1.56 & 3.12 & 19.68 & 24.79 & 15.74 & 67.65 & 84.26 & 32.35 & 14898.29 & 3152.42 & 10.41 & 1.29 & 1.67 & 4.04 \\
\hline 2016/17 & 1.67 & 6.63 & 19.77 & 40.94 & 16.27 & 59.76 & 83.73 & 40.24 & 19654.32 & 4552.52 & 5.32 & 1.32 & 1.32 & 3.31 \\
\hline 2017/18 & 1.33 & 7.48 & 12.49 & 27.64 & 6.92 & 52.41 & 93.08 & 47.59 & 24643.6 & 3225.51 & 4.89 & 1.63 & 1.07 & 3.98 \\
\hline 2018/19 & 1.13 & 6.39 & 9.14 & 19.71 & 12.52 & 42.94 & 87.48 & 57.06 & 32452.07 & 3054.53 & 5.00 & 1.97 & 0.85 & 3.13 \\
\hline Mean & 2.18 & 6.02 & 22.17 & 32.10 & 11.27 & 55.81 & 88.73 & 44.19 & 12891.04 & 1928.03 & 7.27 & 1.68 & 2.23 & 7.07 \\
\hline SD & 1.03 & 1.64 & 15.05 & 8.49 & 3.21 & 6.43 & 3.21 & 6.43 & 9922.81 & 1437.92 & 2.38 & 0. & 1.00 & 3.56 \\
\hline
\end{tabular}

Return on assets is 2.70 percent in $2009 / 10$ to the highest 3.86 percent in 2011/12 to a minimum of 1.13 percent in 2018/19 for life insurance companies. The nonlife insurance companies earned a return on assets of 4.81 percent in 2009/10 with a 
maximum of 8.32 percent in 2013/14 and a minimum of 3.12 percent in 2015/16 to 6.39 percent in 2018/19. The average return on assets of the non-life insurance company is 6.02 percent over the life insurance companies of 2.18 percent only. An independentsamples t-test was conducted to compare the variables in life and non-life insurance companies and to test the alternative hypothesis as there is a significant difference between life and non-life insurance companies. There was a significant difference in ROA of life insurance $(m=2.168, s d=1.870)$ and non-life insurance $(m=5.880, s d=$ 5.052) conditions; $\mathrm{t}(138)=-5.768, \mathrm{p}=0.000$. These results suggest that non-life insurance companies have a higher return on assets. It reveals that there is a significant difference between life and non-life insurance company based on ROA.

The earning per share of life insurance companies is Rs. 18.54 in 2009/10 to the highest Rs. 50 in 2012/13 to a minimum of Rs. 9.14 in 2018/19. The non-life insurance companies have earnings per share of Rs 23.96 in 2009/10 with a maximum of Rs43.38 in 2012/13 and a minimum of Rs. 19.71 in 2018/19. The average earning per share of the non-life insurance company is Rs. 32.10 over the life insurance companies of Rs. 22.17 during the study period. An independent-samples t-test was conducted to compare the variables in life and non-life insurance companies. There was a significant difference in the scores for EPS of life insurance $(m=22.17, s d=28.99)$ and non-life insurance $(m=$ $32.10, s d=26.70)$ conditions; $t(138)=-2.107, p=0.000$. This exhibits that the non-life insurance companies have higher earnings per share as compared to life insurance companies in Nepal.

The total debt ratio is 11.25 percent in $2009 / 10$ to the highest 16.27 percent in 2016/17 to a minimum of 6.92 percent in 2017/18 to 12.52 percent in 2018/19 for life insurance companies. The average total debt ration of the non-life insurance companies is 53.47 percent in 2009/10 with a maximum of 67.65 percent in 2015/16 and a minimum of 42.94 percent in 2018/19. The average total debt ratio of the non-life insurance company is 55.81 percent over the life insurance companies of 11.27 percent. An independent-samples t-test was conducted to compare the mean between life and non-life insurance companies. There was a significant difference in the scores for TDR of life insurance $(m=11.20, s d=12.73)$ and non-life insurance $(m=55.04, s d=20.32)$ conditions; $t(138)=-15.30, p=0.000$. These demonstrate that non-life insurance companies have a higher total debt ratio than life insurance companies.

Equity to total assets of life insurance companies is 88.75 percent in $2009 / 10$ to highest 93.08 percent in 2017/18, a minimum of 83.73 percent in 2016/17 to 87.48 percent in 2018/19 for life insurance companies. Equity to total assets of 46.53 percent in 2009/10 with a maximum of 57.06 percent in 2018/19 and a minimum 32.35 percent in 2015/16 for the non-life insurance companies. The average equity to total assets of the non-life insurance company is 44.19 percent over the life insurance companies of 88.73 percent. An independent-samples t-test was conducted to compare the mean between life and non-life insurance companies. There was a significant difference in the scores for ETA of life insurance $(m=87.72, s d=13.47)$ and non-life insurance $(m=43.66$, $s d=$ 20.00) conditions; $t(138)=15.283, p=0.000$. This outcome shows that the life insurance companies have higher equity to total assets ratio.

The average size of the life insurance company is Rs 2402.44 million in 2009/10 to the highest Rs. 32452 million in 2018/19 with an increasing trend for the life insurance companies. The non-life insurance companies' size of Rs. 503.01 million in 2009/10 to maximum Rs 4552.52 million in 2016/17 to 3054.53 million in 2018/19. The average size of the non-life insurance company is 1928.03 million over the life insurance companies of Rs. 12891.04 million. An independent-samples t-test was conducted to compare the variables in life and non-life insurance companies. There was a significant 
difference in the scores for SIZE of life insurance $(m=13031.70, s d=16194.18)$ and non-life insurance $(m=2187.59, s d=2855.22)$ conditions; $t(138)=5.517, p=0.000$. These findings show that the life insurance companies have a higher size in terms of investment in total assets than the non-life insurance companies.

The liquidity position of the life insurance company is 7.20 times in 2009/10 to the highest 11.09 times and lowest of 4.89 times in 2017/18 to 5 times in 2018/19 with the fluctuating trend for the life insurance companies. The non-life insurance company's liquidity position shows an average of 1.56 times in 2009/10 to a maximum of 3.77 times in $2013 / 14$ to 1.97 times in 2018/19. The average liquidity of the non-life insurance company is 1.68 times over the life insurance companies of 7.27 times. An independentsamples t-test was conducted to compare the variables in life and non-life insurance companies. There was a significant difference in the scores for LQ of life insurance ( $m=$ $7.27, s d=5.19)$ and non-life insurance $(m=1.68, s d=2.04)$ conditions; $t(138)=$ $8.377, p=0.000$. the results demonstrate that the non-life insurance companies have lower liquidity as compared to the life insurance companies.

The tangibility position is 2.68 percent in $2009 / 10$ to the highest 3.65 percent in 2010/11 to a minimum of 0.85 percent in 2018/19 for the life insurance companies. The non-life insurance companies have the tangibility ratio of 11.99 percent in 2009/10 with a maximum of 12.18 percent in 2010/11 and a minimum of 3.13 percent in 2018/19. The average tangibility of the non-life insurance company is 7.07 percent over the life insurance companies of 2.23 percent. An independent-samples t-test was conducted to compare the variables in life and non-life insurance companies. There was a significant difference in the scores for TAN of life insurance $(m=2.21$, $s d=1.85)$ and non-life insurance $(m=7.01, s d=6.76)$ conditions; $t(138)=-5.74, p=0.000$. The outcome reflects that the life insurance companies have lower tangibility than the non-life insurance companies.

\section{Relationship between Firm Specific and Financial Performance Variables}

The bivariate correlation coefficient between dependent and independent variables has been used as per the descriptive statistics presented above. The association among the variables has been presented in Table 3 expressed through correlation coefficients.

Table 3

Pearson's Correlation Coefficients for Dependent and Independent Variables

\begin{tabular}{llllllll}
\hline Variables & ROA & EPS & TDR & ETA & SIZE & LQ & TAN \\
\hline ROA & 1 & & & & & & \\
EPS & $.627^{* *}$ & 1 & & & & & \\
TDR & $.338^{* *}$ & 0.121 & 1 & & & & \\
ETA & $-.338^{* *}$ & -0.121 & $-1.000^{* *}$ & 1 & & & \\
SIZE & $-.284^{* *}$ & -0.021 & $-.407^{* *}$ & $.407^{* *}$ & 1 & & \\
LQ & $-.267^{* *}$ & -0.137 & $-.602^{* *}$ & $.602^{* *}$ & $.272^{* *}$ & 1 & \\
TAN & $.299^{* *}$ & $.212^{*}$ & $.365^{* *}$ & $-.365^{* *}$ & $-.289^{* *}$ & $-.305^{* *}$ & 1 \\
\hline
\end{tabular}

Notes: The asterisk signs $\left({ }^{* *}\right)$ and $(*)$ indicate that the results are significant at 1 percent and 5 percent levels respectively.

The correlation result shows that there is a positive association between ROA and EPS. It indicates that an increase in return on assets leads to an increase in EPS. The correlation between return on assets and the total debt ratio is positive that justifies the leveraged benefit of debt capital in the insurance industry. The positive correlation 
coefficient between return on assets and tangibility indicates more investment in tangible assets generates higher returns on assets in the industry. There is a negative association between return on assets and equity to total assets; it indicates that an increase in equity to total assets leads to a decrease in ROA. An increase in size decreases returns on assets as indicated by the negative correlation between these variables. An increase in liquidity decreases the return on assets as less effective utilization of current assets as indicated by the negative correlation coefficient between these variables. Earnings per share are positively correlated with the total debt ratio and negatively correlated with the equity to total assets ratio. It indicates that the industry is taking benefit of leverage.

There is a negative correlation between earning per share with size and liquidity that justifies the over-investment in assets and current assets that are not efficiently utilized. Investment in tangible assets increases the earning per share in the insurance industry as indicated by the positive correlation coefficient between these variables. Equity and debt are the alternative sources of financing increase in one component of this variable decrease another variable as suggested by a negative correlation between equity and debt capital. There is a negative association between total debt ratios with size; it clarifies that an increase in size decreases the total debt ratio due to risk minimization through equity financing. The negative correlation between total debt ratio and size and liquidity indicates an increase in size and liquidity decreases the debt ratio in the insurance industry of Nepal. Tangible assets are financed by the debt capital as indicated by the positive correlation between total debt ratio and tangibility. Total assets and current assets are financed through equity financing in this industry that is denoted by a positive correlation between equity to total assets with size and liquidity but a negative relationship between tangibility and equity to total assets. An increase in size increases the liquidity and decrease the tangibility of the insurance industry in Nepal. Liquidity and tangibility are negatively correlated; it means an increase in liquidity decrease the tangibility in the industry.

\section{Impact of Firm Specific Factors on Financial Performance}

As per the direction and magnitude of correlation coefficient, regression analysis is used to find out the influence of independent variables on the dependent variable. Table 4 depicts the impact on return on assets as the dependent variable for the life insurance companies.

\section{Table 4}

\begin{tabular}{|c|c|c|c|c|c|c|c|c|c|}
\hline Model & Intercept & TDR & ETA & SIZE & LQ & TAN & EPS & R2 & F-Value \\
\hline 1 & $\begin{array}{l}1.829 * * \\
(6.221)\end{array}$ & $\begin{array}{l}0.031^{*} \\
(1.787)\end{array}$ & & & & & & 0.045 & 3.195* \\
\hline 2 & $\begin{array}{l}4.935^{* *} \\
(3.168)\end{array}$ & & $\begin{array}{l}-0.031^{*} \\
(-1.787)\end{array}$ & & & & & 0.045 & $3.195 *$ \\
\hline 3 & $\begin{array}{l}2.620 * * \\
(9.526)\end{array}$ & & & $\begin{array}{l}-0.000 * * \\
(-2.558)\end{array}$ & & & & 0.088 & $6.541^{* *}$ \\
\hline 4 & $\begin{array}{l}2.554 * * \\
(6.661)\end{array}$ & & & & $\begin{array}{l}-0.052 * * \\
(-1.199)\end{array}$ & & & 0.021 & $1.439 * *$ \\
\hline 5 & $\begin{array}{l}1.037 * * \\
(3.416)\end{array}$ & & & & & $\begin{array}{l}0.513 * * \\
(4.875)\end{array}$ & & 0.259 & $23.769 * *$ \\
\hline 6 & $\begin{array}{l}1.577 * * \\
(6.147)\end{array}$ & & & & & & $\begin{array}{l}0.027 * * \\
(3.846)\end{array}$ & 0.179 & $14.789 * *$ \\
\hline 7 & $\begin{array}{l}1.599 * * \\
(3.223)\end{array}$ & & & $\begin{array}{l}-0.000^{*} \\
(-1.354)\end{array}$ & $\begin{array}{l}-0.029 * \\
(-0.762)\end{array}$ & $\begin{array}{l}0.454^{*} \\
(4.061)\end{array}$ & & 0.285 & $8.762 *$ \\
\hline 8 & $\begin{array}{l}3.633^{* * *} \\
(2.770)\end{array}$ & & $\begin{array}{l}-0.029 * \\
(-1.820)\end{array}$ & $\begin{array}{l}-0.000 * * \\
(-1.640)\end{array}$ & $\begin{array}{l}-0.012 \\
(-0.310)\end{array}$ & $\begin{array}{l}0.351 \\
(3.243)\end{array}$ & $\begin{array}{l}0.023 * * \\
(3.477)\end{array}$ & 0.416 & $9.116^{* *}$ \\
\hline 9 & $\begin{array}{l}3.633^{* *} \\
(2.770)\end{array}$ & $\begin{array}{l}0.029 * \\
(1.820)\end{array}$ & & $\begin{array}{l}-0.000 * * \\
(-1.640)\end{array}$ & $\begin{array}{l}-0.012 \\
(-0.310)\end{array}$ & $\begin{array}{l}0.351 \\
(3.243)\end{array}$ & $\begin{array}{l}0.023 * * \\
(3.477)\end{array}$ & 0.416 & $9.116 * *$ \\
\hline
\end{tabular}

Prithvi Academic Journal, Volume 4, May 2021 [pp. 39-55] 
Notes: The asterisk signs $(* *)$ and $(*)$ indicate that the coefficients are significant at 1 percent and 5 percent levels respectively. The value in the parentheses indicates $t$-value

Table 4 depicts nine models to show the impact of firms specific factors on return on assets. Model 1 to Model 6 exhibits the impact of TDR, ETA, SIZE, TAN and EPS on ROA individually. TDR, TAN and EPS have a significant impact on ROA. However, ETA, SIZE and LQ have negative impact on ROA. Model 7shows the impact of SIZE, LQ and TAN on ROA. Only TAN has a positive impact on ROA. Model 8 represents the impact of ETA, SIZE, LQ, TAN and EPS on ROA. The results indicate that only TAN and EPS have a positive impact on ROA. Lastly, Model 9 represents the influence on TDR, SIZE, LQ, TAN and EPS on ROA. SIZE and LQ have a negative influence on ROA.

\section{Table 5}

Impact of Firm Specific Factors on Earning Per Share of Life Insurance Companies

\begin{tabular}{|c|c|c|c|c|c|c|c|c|c|}
\hline Model & Intercept & TDR & ETA & SIZE & LQ & TAN & ROA & R2 & F-Value \\
\hline 1 & $\begin{array}{l}23.918^{* *} \\
(5.120)\end{array}$ & $\begin{array}{c}0.155^{*} \\
(0.561)\end{array}$ & & & & & & 0.005 & 0.314* \\
\hline 2 & $\begin{array}{l}8.435 * * \\
(0.341)\end{array}$ & & $\begin{array}{l}-0.155^{*} \\
(-0.561)\end{array}$ & & & & & 0.005 & $0.314 *$ \\
\hline 3 & $\begin{array}{l}20.342^{* *} \\
(4.552)\end{array}$ & & & $\begin{array}{l}-0.000 \\
(-0.653)\end{array}$ & & & & 0.006 & 0.426 \\
\hline 4 & $\begin{array}{l}26.519 * * \\
(4.552)\end{array}$ & & & & $\begin{array}{l}-0.598 * \\
(-0.889)\end{array}$ & & & 0.011 & $0.790 *$ \\
\hline 5 & $\begin{array}{l}12.299 * * \\
(2.336)\end{array}$ & & & & & $\begin{array}{l}4.431 * * \\
(2.430)\end{array}$ & & 0.080 & $5.904^{* *}$ \\
\hline 6 & $\begin{array}{l}7.837 * * \\
(1.603)\end{array}$ & & & & & & $\begin{array}{l}6.579 * * \\
(3.846)\end{array}$ & 0.179 & $14.789 * *$ \\
\hline 7 & $\begin{array}{l}8.891 * * \\
(5.265)\end{array}$ & & & $\begin{array}{l}0.000 \\
(1.543)\end{array}$ & $\begin{array}{l}-0.381 \\
(-0.585)\end{array}$ & $\begin{array}{l}5.241^{*} \\
(2.713)\end{array}$ & & 0.117 & $2.906^{*}$ \\
\hline 8 & $\begin{array}{l}-32.633 \\
(-1.353)\end{array}$ & & $\begin{array}{l}-0.393 \\
(-1.380)\end{array}$ & $\begin{array}{l}0.000^{*} \\
(1.855)\end{array}$ & $\begin{array}{l}-0.611 \\
(-0.902)\end{array}$ & $\begin{array}{l}1.853 \\
(0.913)\end{array}$ & $\begin{array}{l}6.969 * * \\
(3.474)\end{array}$ & 0.263 & $4.573^{* *}$ \\
\hline 9 & $\begin{array}{l}-32.633 \\
(-1.353)\end{array}$ & $\begin{array}{l}0.393 \\
(1.380)\end{array}$ & & $\begin{array}{l}0.000^{*} \\
(1.855)\end{array}$ & $\begin{array}{l}-0.611 \\
(-0.902)\end{array}$ & $\begin{array}{l}1.853 \\
(0.913)\end{array}$ & $\begin{array}{l}6.969 * * \\
(3.474)\end{array}$ & 0.263 & $4.573^{* *}$ \\
\hline
\end{tabular}

Notes: The asterisk signs $(* *)$ and $(*)$ indicate that the coefficients are significant at 1 percent and 5 percent levels respectively. The value in the parentheses indicates $t$-value

Table 5 depicts nine models to show the impact of firms specific factors on EPS. Model 1 to Model 6 exhibit the impact of TDR, SIZE, TAN and ROA on EPS individually. TDR, TAN and ROA have a significant impact on EPS. However, ETA SIZE and LQ have a negative impact on ROA. Model 7 shows the impact of SIZE, LQ and TAN on ROA. Only TAN has a positive impact on ROA. Model 8 represents the impact of ETA, SIZE, LQ, TAN and ROA on EPS. The results show that only SIZE, TAN, and ROA have a positive impact on EPS. Lastly, Model 9 represents the influence on TDR, SIZE, LQ, TAN and ROA on EPS. Only LQ has a negative influence on EPS.

\section{Table 6}

\begin{tabular}{|c|c|c|c|c|c|c|c|c|c|}
\hline Model & Intercept & TDR & ETA & SIZE & LQ & TAN & EPS & $\mathrm{R} 2$ & F-Value \\
\hline 1 & $\begin{array}{l}\text { 7.753** } \\
(4.189)\end{array}$ & $\begin{array}{l}-0.031 * \\
(-0.990)\end{array}$ & & & & & & 0.014 & 0.979* \\
\hline 2 & $\begin{array}{l}4.651^{* *} \\
(3.079)\end{array}$ & & $\begin{array}{l}0.031 * \\
(0.031)\end{array}$ & & & & & 0.014 & $979 *$ \\
\hline 3 & $\begin{array}{l}6.386^{* *} \\
(7.287)\end{array}$ & & & $\begin{array}{l}-0.000 * * \\
(-0.576)\end{array}$ & & & & 0.05 & $0.332 * *$ \\
\hline 4 & $\begin{array}{l}5.529 * * \\
(7.040)\end{array}$ & & & & $\begin{array}{l}0.293^{*} \\
(0.981)\end{array}$ & & & 0.014 & $0.962 *$ \\
\hline 5 & $\begin{array}{l}5.573 * * \\
(6.307)\end{array}$ & & & & & $\begin{array}{l}0.063^{* *} \\
(0.698)\end{array}$ & & 0.070 & $0.478 * *$ \\
\hline 6 & $\begin{array}{l}1.094^{* *} \\
(1.958)\end{array}$ & & & & & & $\begin{array}{l}0.154^{* *} \\
(11.444)\end{array}$ & 0.568 & $13.964^{* *}$ \\
\hline
\end{tabular}

Prithvi Academic Journal, Volume 4, May 2021 [pp. 39-55] 


\begin{tabular}{|c|c|c|c|c|c|c|c|c|c|}
\hline 7 & $\begin{array}{l}5.308^{* *} \\
(3.859)\end{array}$ & & & $\begin{array}{l}-0.000^{*} \\
(-0.366)\end{array}$ & $\begin{array}{l}0.313^{*} \\
(1.034)\end{array}$ & $\begin{array}{l}0.061^{*} \\
(0.633)\end{array}$ & & 0.052 & $0.564^{* *}$ \\
\hline 8 & $\begin{array}{l}1.075 * * \\
(0.941)\end{array}$ & & $\begin{array}{l}0.026^{*} \\
(1.414)\end{array}$ & $\begin{array}{l}-0.000 * * \\
(-2.045)\end{array}$ & $\begin{array}{l}0.016 \\
(0.091)\end{array}$ & $\begin{array}{l}0.064 \\
(1.131)\end{array}$ & $\begin{array}{l}0.158^{* *} \\
(11.657)\end{array}$ & 0.691 & $28.609 * *$ \\
\hline 9 & $\begin{array}{l}1.075^{* *} \\
(0.941) \\
\end{array}$ & $\begin{array}{l}-0.026^{*} \\
(-1.414)\end{array}$ & & $\begin{array}{l}-0.000 * * \\
(-2.045)\end{array}$ & $\begin{array}{l}0.016 \\
(0.091) \\
\end{array}$ & $\begin{array}{l}0.064 \\
(1.131) \\
\end{array}$ & $\begin{array}{l}0.158^{* *} \\
(11.657)\end{array}$ & 0.691 & $28.609 * *$ \\
\hline
\end{tabular}

Notes: The asterisk signs $(* *)$ and $(*)$ indicate that the coefficients are significant at 1 percent and 5 percent levels respectively. The value in the parentheses indicates $t$-value

Table 5 depicts nine models to show the impact of firms specific factors on ROA of the non-life insurance companies in Nepal. Model 1 to Model 6 exhibit the impact of TDR, SIZE, TAN and EPS on ROA individually. ETA, LQ, TAN and EPS have a significant impact on ROA. However, TDR and SIZE have a negative impact on ROA. Model 7 shows the impact of SIZE, LQ and TAN on ROA. Only SIZE has a negative impact on ROA. Model 8 represents the impact of ETA, SIZE, LQ, TAN and EPS on ROA. The results depict that only SIZE has a negative impact on ROA. Lastly, Model 9 represents the influence on TDR, SIZE, LQ, TAN and EPS on ROA. TDR and SIZE have a negative influence on ROA.

\section{Table 7}

Impact of Firm Specific Factors on Earning Per Share of Non-Life Insurance Companies

\begin{tabular}{|c|c|c|c|c|c|c|c|c|c|}
\hline Model & Intercept & TDR & ETA & SIZE & LQ & TAN & ROA & R2 & F-Value \\
\hline 1 & $\begin{array}{l}33.323^{* *} \\
(3.384)\end{array}$ & $\begin{array}{l}-0.022^{*} \\
(-0.132)\end{array}$ & & & & & & 0.016 & $0.017^{*}$ \\
\hline 2 & $\begin{array}{l}31.128 * * \\
(3.872)\end{array}$ & & $\begin{array}{l}0.022^{*} \\
(0.132)\end{array}$ & & & & & 0.016 & $0.017 *$ \\
\hline 3 & $\begin{array}{l}30.131 * * \\
(6.507)\end{array}$ & & & $\begin{array}{l}-0.010 \\
(-0.589)\end{array}$ & & & & 0.050 & 0.347 \\
\hline 4 & $\begin{array}{l}29.389 * * \\
(6.032)\end{array}$ & & & & $\begin{array}{l}1.612^{*} \\
(1.022)\end{array}$ & & & 0.015 & $1.044 *$ \\
\hline 5 & $\begin{array}{l}27.962 * * \\
(6.032)\end{array}$ & & & & & $\begin{array}{l}0.585^{*} \\
(1.226)\end{array}$ & & 0.022 & $1.504^{* *}$ \\
\hline 6 & $\begin{array}{l}1.094^{* *} \\
(1.958)\end{array}$ & & & & & & $\begin{array}{l}0.154^{* *} \\
(11.444)\end{array}$ & 0.568 & $13.964^{* *}$ \\
\hline 7 & $\begin{array}{l}19.825^{* *} \\
(2.771)\end{array}$ & & & $\begin{array}{l}-0.002 \\
(1.037)\end{array}$ & $\begin{array}{l}1.817 \\
(1.155)\end{array}$ & $\begin{array}{l}0.794^{*} \\
(1.582)\end{array}$ & & 0.056 & $1.298 *$ \\
\hline 8 & $\begin{array}{l}1.727 * * \\
(0.288)\end{array}$ & & $\begin{array}{l}0.112 \\
(1.162)\end{array}$ & $\begin{array}{l}0.002 * \\
(2.275)\end{array}$ & $\begin{array}{l}0.652 \\
(0.706)\end{array}$ & $\begin{array}{l}0.528 \\
(1.826)\end{array}$ & $\begin{array}{l}4.309^{* *} \\
(11.657)\end{array}$ & 0.698 & $29.536 * *$ \\
\hline 9 & $\begin{array}{l}1.727 * * \\
(0.288)\end{array}$ & $\begin{array}{l}-0.112 \\
(-1.162)\end{array}$ & & $\begin{array}{l}0.002^{*} \\
(2.275)\end{array}$ & $\begin{array}{l}0.652 \\
(0.706)\end{array}$ & $\begin{array}{l}0.528 \\
(1.826)\end{array}$ & $\begin{array}{l}4.309 * * \\
(11.657)\end{array}$ & 0.698 & 29.536 ** \\
\hline
\end{tabular}

Table 5 depicts nine models to show the impact of firms specific factors on EPS. Model 1 to Model 6 show the impact of TDR, SIZE, TAN and ROA on EPS individually. ETA, LQ, TAN and ROA have a significant impact on EPS. However, TDR, ETA and SIZE have a negative impact on EPS. Model 7 shows the impact of SIZE, LQ and TAN on ROA. Only SIZE has a negative impact on EPS. Model 8 represents the impact of ETA, SIZE, LQ, TAN and ROA on EPS. The results demonstrate that none of the firm specific factors has a negative impact on EPS. Lastly, Model 9 represents the influence on TDR, SIZE, LQ, TAN and ROA on EPS. Only TDR has a negative influence on EPS.

\section{Table 8}

Impact of Major Variables on Return on Assets

\begin{tabular}{|c|c|c|c|c|c|c|c|c|}
\hline Intercept & TDR & ETA & SIZE & $\mathrm{LQ}$ & TAN & EPS & $\mathrm{R} 2$ & F-Value \\
\hline $\begin{array}{l}2.360^{* *} \\
(4.411)\end{array}$ & $\begin{array}{l}0.052^{* *} \\
(4.213)\end{array}$ & & & & & & 0.114 & $17.747^{* *}$ \\
\hline $\begin{array}{l}7.549 * * \\
(8.517)\end{array}$ & & $\begin{array}{l}-0.052 * * \\
(-4.213)\end{array}$ & & & & & 0.114 & $11.367 * *$ \\
\hline $\begin{array}{l}4.807 * * \\
(11.981)\end{array}$ & & & $\begin{array}{l}-0.000 * * \\
(-3.483)\end{array}$ & & & & 0.081 & $12.484^{* *}$ \\
\hline $5.155 * *$ & & & & $-0.236 * *$ & & & 0.071 & $10.619 * *$ \\
\hline
\end{tabular}

Prithvi Academic Journal, Volume 4, May 2021 [pp. 39-55] 


\begin{tabular}{|c|c|c|c|c|c|c|c|c|}
\hline$(10.850)$ & & & & $(-3.259)$ & & & & \\
\hline $3.019 * *$ & & & & & $0.233^{* *}$ & & 0.090 & $13.581^{* *}$ \\
\hline$(6.671)$ & & & & & (3.685) & & & \\
\hline $1.534^{* *}$ & & & & & & $0.095^{* *}$ & 0.393 & $89.330 * *$ \\
\hline (3.925) & & & & & & $(9.451)$ & & \\
\hline $4.461^{* *}$ & & & $-0.000^{*}$ & $-0.138 *$ & $0.154^{*}$ & & 0.154 & $8.233^{* *}$ \\
\hline$(6.984)$ & & & $(-2.192)$ & $(-1.854)$ & $(2.234)$ & & & \\
\hline $3.626^{* *}$ & & $-0.024^{*}$ & $-0.000 * *$ & -0.023 & 0.044 & $0.089 * *$ & 0.498 & $26.577 * *$ \\
\hline (4.145) & & $(-1.872)$ & $(-2.734)$ & $(-0.338)$ & $(0.831)$ & $(9.352)$ & & \\
\hline $1.692^{*}$ & $0.018^{*}$ & & $-0.000 * *$ & -0.076 & 0.047 & $0.085^{* *}$ & 0.489 & $25.604^{* *}$ \\
\hline$(2.050)$ & (1.404) & & $(-2.739)$ & $(-1.060)$ & $(0.890)$ & (8.985) & & \\
\hline
\end{tabular}

Notes: The asterisk signs $(* *)$ and $\left({ }^{*}\right)$ indicate that the coefficients are significant at 1 percent. The value in the parentheses indicates $t$-value

Table 8 exhibits the regression model among the variables of both life and nonlife insurance companies of Nepal. The model fit has been represented by $f$ value. All the regression models are significant at 1 percent level of significance. Model 1 to 6 represent the impact of single independent variables on ROA. Model 7 represents the impact of firm specific variables on ROA. Likewise, model 8 and 9 represent the impact of capital and structure and firm specific variables on ROA. The beta coefficient is positive for the total debt ratio. This indicates that the total debt ratio directly influences return on assets. The finding is alike to Margaritis and Psillaki (2010), Naser et al. (2011) and Zhang (2011). Similarly, the beta coefficients are negative for equity to total assets. This indicates that equity to total assets negatively affects return on assets. Oladele, Sulaiman and Akeke (2012) and Trujillo-Ponce (2013) also replicated similar findings. Likewise, the beta coefficients are negative for firm size. It indicates that firm size affect more on return on assets. The result is similar to the finding of Vijayakumar and Tamizhselvan (2010).

Similarly, the beta coefficients are negative for the liquidity ratio. This indicates that the liquidity ratio hurts return on assets. The findings correlate with the findings of Wang (2002) and Dawood (2014). The study also reveals that the beta coefficients are positive for asset tangibility. This indicates that asset tangibility has a positive impact on return on assets. This finding is similar to the findings of Mehari and Aemiro (2013) and Oziomobo and Ghazali (2016). Likewise, the beta coefficients are positive for earning per share. This indicates that earnings per share significantly impact return on assets.

Table 9 exhibits the regression results of the TDR, ETA, firm SIZE, LIQ and TAN on EPS.

Table 9

Impact of Major Variables on Earning Per Share

\begin{tabular}{|c|c|c|c|c|c|c|c|c|}
\hline Intercept & TDR & ETA & SIZE & LQ & TAN & ROA & $\mathrm{R} 2$ & F-Value \\
\hline $\begin{array}{l}22.987 * * \\
(6.147)\end{array}$ & $\begin{array}{l}0.124 \\
\quad(1.436)\end{array}$ & & & & & & 0.015 & 2.063 \\
\hline $\begin{array}{l}35.353 * * \\
(5.707)\end{array}$ & & $\begin{array}{l}-0.124^{*} \\
(-1.436)\end{array}$ & & & & & 0.015 & $2.063^{*}$ \\
\hline $\begin{array}{l}27.473^{* *} \\
(9.905)\end{array}$ & & & $\begin{array}{l}-0.000 \\
(-0.241)\end{array}$ & & & & 0.004 & 0.058 \\
\hline $\begin{array}{l}30.715^{* *} \\
(9.488)\end{array}$ & & & & $\begin{array}{l}-0.800^{*} \\
(-1.624)\end{array}$ & & & 0.019 & $2.637 *$ \\
\hline $\begin{array}{l}22.063^{* * *} \\
(7.180)\end{array}$ & & & & & $\begin{array}{l}1.091^{* *} \\
(2.545)\end{array}$ & & 0.045 & $6.478 * *$ \\
\hline $\begin{array}{l}10.097 * * \\
(3.893)\end{array}$ & & & & & & $\begin{array}{l}4.155^{* *} \\
(9.451)\end{array}$ & 0.393 & $89.330^{* *}$ \\
\hline $\begin{array}{l}23.688 * * \\
(5.265)\end{array}$ & & & $\begin{array}{l}0.000 \\
(0.707)\end{array}$ & $\begin{array}{l}-0.541 \\
(-1.036)\end{array}$ & $\begin{array}{l}1.039 * \\
(2.245)\end{array}$ & & 0.054 & $2.593 *$ \\
\hline $\begin{array}{l}-0.741 \\
(-0.113)\end{array}$ & & $\begin{array}{l}0.086 \\
(0.950)\end{array}$ & $\begin{array}{l}0.000^{*} \\
(2.283)\end{array}$ & $\begin{array}{l}-0.170 \\
(-0.352)\end{array}$ & $\begin{array}{l}0.418 \\
(1.117)\end{array}$ & $\begin{array}{l}4.446 * * \\
(9.352)\end{array}$ & 0.428 & $20.053^{* *}$ \\
\hline $\begin{array}{l}7.378 \\
(1.234) \\
\end{array}$ & $\begin{array}{l}-0.081 \\
(-0.080)\end{array}$ & & $\begin{array}{l}0.000 \\
(2.323) \\
\end{array}$ & $\begin{array}{l}-0.024^{*} \\
(-0.046) \\
\end{array}$ & $\begin{array}{l}0.422 \\
(1.108) \\
\end{array}$ & $\begin{array}{l}4.399 * * \\
(8.985) \\
\end{array}$ & 0.409 & $18.543^{* *}$ \\
\hline
\end{tabular}

Prithvi Academic Journal, Volume 4, May 2021 [pp. 39-55] 
Notes: The asterisk signs $\left({ }^{* *}\right)$ and $(*)$ indicate that the coefficients are significant at 1 percent and 5 percent levels respectively. The value in the parentheses indicates $t$-value

Table 5 exhibits the regression model among the variables. The model fit has been represented by $f$ value. All the regression models are significant at 1 percent level of significance. Model 1 to 6 represent the impact of single independent variables on EPS. Model 7 represents the impact of firm specific variables on EPS. Likewise, Model 8 and 9 represent the impact of capital structure and firm specific variables on EPS. Table 5 presents the influence of major variables namely TDR, ETA, Firm's Size, LQ, TAN and ROA on EPS. The result shows that the beta coefficients are positive for the total debt ratio. This indicates that the total debt ratio has a positive impact on earnings per share. This result is similar to the finding of Pradhan and Bhattarai (2016). Similarly, the beta coefficients are negative for equity to total assets. This indicates that equity to total assets harms earnings per share. However, this finding is not consistent with the finding of Ramadan (2011). Likewise, the beta coefficients are negative for the firm size. It indicates that the firm size hurts earnings per share. This finding is not consistent with the findings of Kipesha (2013).

Similarly, the beta coefficients are negative for the liquidity ratio. This indicates that the liquidity ratio harms earnings per share. This finding is similar to the findings of Bourke (1989) and Peker and Baki (2011). The study also reveals that the beta coefficients are positive for asset tangibility. This indicates that asset tangibility has a positive impact on earnings per share.

The total debt ratio of the non-life insurance industry is greater than the life insurance industry and earnings per share are also higher in the non-life insurance industry than the life insurance industry in Nepal. It means a higher equity portion in the capital structure of the life insurance industry of Nepal resulted from a lower rate of profitability with the comparison of the non-life insurance industry during the study period. The size of both life and non-life industry has been gradually increasing during this study period but the average size of the life insurance industry is more than the nonlife insurance industry in Nepal. The result justifies that the higher firm size has reduced the profitability position of the life insurance industry. The liquidity position of the life insurance industry fluctuates more than the non-life insurance industry. The result further justifies that the higher the liquidity the lower the financial performance or profitability. and It shows the less effective investment in current assets. The ratio of tangibility in the non-life insurance industry is greater than the life insurance industry in Nepal during the study period. The result suggests that a higher tangibility provides a higher level of financial performance in the insurance industry.

\section{CONCLUSIONS}

The major conclusion of this study is that the insurance companies having a high debt ratio have better financial performance. This finding is similar to the findings of Margaritis and Psillaki (2010), Naser et al. (2011), Zhang (2011), Salim and Yadav (2012), Almajali and Shamsuddin (2019), Jaishi (2020) and Bhattarai (2020). There is a greater leverage effect to increase financial performance in the insurance companies of Nepal. An increase in the debt ratio and tangibility increases return on assets. It implies that investment in tangible assets can help to increase the financial performance in the insurance sector of Nepal. An increase in equity, size and liquidity decreases return on assets in the industry. The impact of debt ratio and tangibility on earning per share is positive and there is a negative impact of equity, size and liquidity ratio on earning per share. This finding is similar to the findings of Vijayakumar and Tamizhselvan (2010), Oladele, Sulaiman and Akeke (2012), Trujillo-Ponce (2013), Jaishi (2020) and Bhattarai 
(2020). A total debt ratio, equity to total assets ratio, size, liquidity and tangibility are the significant factors in determining the financial performance of the insurance companies in Nepal. In case of life insurance companies, debt ratio, tangibility, EPS and equity are the influencing firm specific variables affecting the financial performance. However, the debt ratio and firm size has a negative impact on return on assets of non-life insurance companies in Nepal. Additionally, the debt ratio also has a negative impact on EPS. There is a significant mean difference in study variables between life and non-life insurance companies. These results suggest that the non-life insurance companies have a higher return on assets, earning per share, total debt ratio and tangibility but lower the equity to total assets ratio, size and liquidity. It indicates that the performance of non-life insurance companies is better in terms of major performance indicators, namely, earning per share and return on assets. The study leads to practical implications for the insurance companies and regulatory bodies. The insurance companies of Nepal interested to improve their financial performance should focus on increasing their leverage and longterm investment and decreasing the proportion of equity, firm size and liquidity. The empirical study has a major implication on life insurance companies to make necessary policy level changes to increase the net insurance premium and other operating income to increase their financial performance.

The study has examined the impact of firm specific factors on the financial performance of insurance companies in Nepal. There remains enough ground of scope in terms of data, models and methodology for studies in the future. The study remains enough ground for further study. The study has only used the secondary data. So, future studies need to employ both primary and secondary sources of data for better results. This study lacks advanced statistical tools such as non-linear statistical tools and bidirectional causality tools. This study only includes insurance companies. Hence, other financial and non-financial institutions like commercial banks, development banks, finance companies, micro-finance, cooperatives, hotels, hydropower companies and other companies listed in NEPSE can be sampled to draw a wider view about the effect of capital structure on the financial performance of Nepali companies. Apart from these variables, the present study only employs firm-specific variables, so the future study should also concentrate on macroeconomic variables macro-economic factors like gross domestic product (GDP) growth rate, interest rate, market conditions, political conditions, the attractiveness of the industry and other non-financial indicators. The Ordinary Least Square (OLS) regression model needs to be used in the future research. The panel data demands some special diagnostic tests like unit root test to check the stationary of data. Similarly, to decide whether the pooled OLS regression model is appropriate or not for the data, the test like Bueusch-Pagen LM test is required. In case, the pooled OLS regression is not appropriate, the Hausman test should be applied to decide either to use the random effect model or fixed effect model. These issues need to be addressed in future research.

\section{REFERENCES}

Ajao, M.G., \& Ogieriakhi, E. (2018). Firm specific factors and performance of insurance firms in Nigeria. Amity Journal of Finance, 3(1), 14-28.

Akintoye, I. R. (2008). Sensitivity of performance to capital structure. European Journal of Social Science, 7 (1), 163-144.

Almajali, M., \& Shamsuddin, Z. (2019). The effect of capital structure on performance of insurance companies: Evidence from Jordan. International Journal of Accounting, 4(20), 64-73. 
Bawa, S.K., \& Chattha, S. (2013). Financial performance of life insurers in Indian insurance industry. Pacific Business Review International, 6(5), 44-51.

Berger, A. N. (1995). The relationship between capital and earnings in banking. Journal of Money, Credit and Banking, 27 (1), 432-456.

Bhattarai, B. (2020). Effects of Capital Structure on Financial Performance of Insurance Companies in Nepal. International Journal of Accounting And Financial Reporting, 10(3), 35. http://doi: 10.5296/ijafr.v10i3.17674

Bourke, P. (1989). Concentration and other determinants of bank profitability in Europe, North America and Australia. Journal of Banking \& Finance, 13(1), 65-79.

Chen, R., \& Wong, K. A. (2004). The determinants of financial health of Asian insurance companies. The Journal of Risk and Insurance, 71(3), 469- 99.

Curak, M., Pepur, S., \& Poposki, K. (2011), Firm and economic factors and performance: Croatian composite insurers. The Business Review Cambridge, 19(1), 136-142.

Dare, F. D., \& Sola, O. (2010). Capital structure and corporate performance in Nigeria petroleum industry: Panel data analysis. Journal of Mathematics and Statistics, 6(2), 168-173.

Dawood, U. (2014). Factors impacting profitability of commercial banks in Pakistan. International Journal of Scientific and Research Publication, 4(3), 1-7.

Enz, R. (2000). The s-curve relation between per-capita income and insurance penetration. The Geneva Papers on Risk and Insurance - Issues and Practice, 25(3), 396-406.

Goyal, A. M. (2013). Impact of capital structure on performance of listed public-sector banks in India. International Journal of Business and Management Invention, 2(10), 35-43.

Iorpev, L., \& Kwanum, I.M. (2012). Capital structure and firm performance: Evidence from manufacturing companies in Nigeria. International Journal of Business and Management Tomorrow, 2(5), 1-5.

Ismail, M. (2013). Determinants of financial performance-the case of general Takaful and insurance companies in Malaysia. International Review of Business Research Papers, 9(6), 111-130.

Jaishi, B. (2020). Capital structure and financial performance of Nepalese insurance companies. The Journal of Nepalese Business Studies, 13(1), 89-106.

Kaya, O. (2015). The effects of firm-specific factors on the profitability of non-life insurance companies in turkey. International Journal of Financial Studies, 3 (4), 510-529.

Kipesha, E. F. (2013). Impact of size and age of firm performance. Evidences from microfinance institutions in Tanzania. Research Journal of Finance and Accounting, 4(5), 105-116.

Maharjan, A. (2017). Relationship between capital structure and profitability: A study of Nepalese commercial banks. Nepalese Journal Management, 4(2), 96-111.

Majumdar, S. K. (1997). The impact of size and age on firm level performance: some evidence from India. Review of Industrial Organization, 12(2), 231-241.

Malik, H. (2011). Determinants of insurance company's profitability: An analysis of insurance sector of Pakistan. Academic Research International, 1(3), 314-320.

Margaritis, D., \& Psillaki, M. (2010). Capital structure, equity ownership and firm performance. Journal of Banking and Finance, 34 (3), 621-632.

Mehari, D., \& Aemiro, T. (2013) Firm specific factors that determine insurance companies` performance in Ethopia. Ethopean Journal of Science, 9(2), 245-255 
Mohammad, R., Ebrati, M., Mohammad, E., \& Bakhshi, F. (2013). Studying the effect of financial leverage and ownership structure on investment growth opportunities. Journal of Basic and Applied Scientific Research, 3(6), 380-385.

Naeem, A., Misbah, B., Sidra, B., \& Hafiz, T. (2016). Capital structure impact on banking sector performance in Pakistan. International Review of Management and Business Research, 5(2), 519-535.

Naser, N., Irbid, J., \& Krassimir, P. (2011). Capital structure of insurance companies in Bahrain. International Journal of Business and Management, 6(11), 138-145.

Oladele, P. O., Sulaiman, A. A., \& Akeke, L. I. (2012). Determinants of bank performance in Nigeria. International Journal of Business and Management, 2(2), 23-48.

Oziomobo, A., \& Ghazali, Z. B. (2016). The impact of capital structure on firm performance: Empirical evidence from Nigeria. Journal of Economics and Finance, 7(4), 23-30.

Peker, I., \& Baki, B. (2011). Performance evaluation in Turkish insurance sector with Grey relationship analysis. International Journal of Economics and Administrative Studies, 4(7), 1-7.

Pradhan, R. S., \& Bhattarai, M. (2016). Financial leverage and firm performance: A case of Nepalese commercial banks. Nepalese Journal of Finance, 3(1), 1-14.

Prahalathan, B., \& Rajan, R.P.C. (2011). The impact of capital structure-choice on firm performance: Emperical investigation of listed companies in Colombo stock exchange, Srilanka. International Journal of Research in Commerce and Management, 2(4), 12-17.

Rajan, R. G., \& Zingales, L. (1995). What do we know about capital structure? Some evidence from international data. The Journal of Finance, 50(5), 1421-1460.

Ramadan, I. Z. (2011). Bank specific determinants of Islamic banks profitability: An empirical study of the Jordanian market. International Journal of Academic Research Papers, 3(6), 73-80.

Safarova, Y. (2010). Factors that determine firm performance of New Zealand listed companies. (Unpublished Masters Dissertation). Auckland University of Technology, New Zealand

Salim, M., \& Yadav, R. (2012). Capital structure and firm performance: evidence from Malaysian listed companies. Social and Behavioral Sciences, 65 (3), 156-166.

Shiu, Y. (2004). Determinants of United Kingdom's general insurance company performance. British Actuarial Journal, 10(5), 1079-1110.

Simerly, R. L., \& Li, M. (2000). Environmental dynamism, capital structure and performance: A theoretical integration and empirical test. Strategic Management Journal, 21(1), 31-49.

Singh, N. P., \& Bagga, M. (2019). The effect of capital structure on profitability: An empirical panel data study. Jindal Journal of Business Research, 4(1), 1-13.

Sunder, L.S., \& Myers, S.C. (1999). Testing static tradeoff against pecking order models of capital structure. Journal of Financial Economics, 51(9), 219-244.

Vijayakumar, A., \& Tamizhselvan, P. (2010). Corporate size and profitability: An empirical analysis. Journal for Bloomers of Research, 3(1), 44-53.

Wang, Y. J. (2002). Liquidity management, operating performance, and corporate value: Evidence from Japan and Taiwan. Journal of Multinational Financial Management, 12 (2), 159-169.

Zhang, M. J. (2011). Firm-level performance impact of IS support for product innovation. European Journal of Innovation Management, 14 (1), 118-13 
Zeitun, R., \& Tian, G. G. (2007). Capital Structure and corporate performance: Evidence from Jordan. Australasian Accounting, Business and Finance Journal, 1(4), 4061.

\section{APPENDIX I}

Selected Sample Companies

\begin{tabular}{|c|c|c|c|}
\hline SN & Name of Companies & Study period & Observations \\
\hline \multirow[t]{2}{*}{1} & Asian $\quad$ Life Insurance Company & 2009/10-2018/19 & \\
\hline & Limited (ALICL) & & 10 \\
\hline \multirow[t]{2}{*}{2} & Gurans Life Insurance Company & 2009/10-2018/19 & \\
\hline & Limited (GLICL) & & 10 \\
\hline \multirow[t]{2}{*}{3} & Himalayan General & 2009/10-2018/19 & \\
\hline & Company Limited (HGI) & & 10 \\
\hline 4 & $\begin{array}{l}\text { Life Insurance Corporation Limited } \\
\text { (LICN) }\end{array}$ & 2009/10-2018/19 & 10 \\
\hline 5 & $\begin{array}{l}\text { National Life Insurance Company } \\
\text { Limited (NLICL) }\end{array}$ & 2009/10-2018/19 & 10 \\
\hline 6 & $\begin{array}{l}\text { Nepal Life Insurance Company } \\
\text { Limited (NLIC) }\end{array}$ & 2009/10-2018/19 & 10 \\
\hline 7 & Prabhu Insurance Limited (PICL) & 2009/10-2018/19 & 10 \\
\hline 8 & $\begin{array}{l}\text { Premier Insurance Company (Nepal) } \\
\text { Limited (PIC) }\end{array}$ & 2009/10-2018/19 & 10 \\
\hline 9 & $\begin{array}{l}\text { Prime Insurance Company (Nepal) } \\
\text { Limited (PLIC) }\end{array}$ & 2009/10-2018/19 & 10 \\
\hline 10 & $\begin{array}{l}\text { Prudential Insurance } \\
\text { Limited (PRIN) }\end{array}$ & 2009/10-2018/19 & 10 \\
\hline 11 & $\begin{array}{l}\text { Sagarmatha Insurance Company } \\
\text { Limited (SICL) }\end{array}$ & 2009/10-2018/19 & 10 \\
\hline 12 & $\begin{array}{l}\text { Shikhar Insurance Company Limited } \\
\text { (SHICL) }\end{array}$ & 2009/10-2018/19 & 10 \\
\hline 13 & $\begin{array}{l}\text { Surya Life Insurance Company } \\
\text { limited (SLICL) }\end{array}$ & 2009/10-2018/19 & 10 \\
\hline \multirow[t]{2}{*}{14} & $\begin{array}{l}\text { United Insurance Company (Nepal) } \\
\text { Limited (UIC) }\end{array}$ & 2009/10-2018/19 & 10 \\
\hline & Total number of observations & & 140 \\
\hline
\end{tabular}

